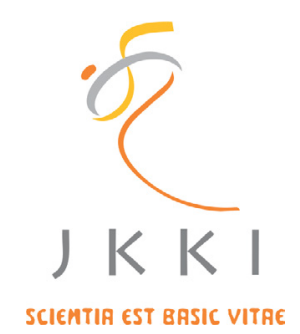

Jurnal Kedokteran dan Kesehatan Indonesia

Indonesian Journal of Medicine and Health

Journal homepage : www.journal.uii.ac.id/index.php/JKKI

\title{
An unusual cause of eyeball rupture: a case report
}

Handy Darmawan ${ }^{1}$

${ }^{1}$ Emergency Department, Dr. Iskak General Hospital, Tulungagung

Case Report

\begin{tabular}{|c|c|}
\hline & \\
\hline ART & \multirow{5}{*}{$\begin{array}{l}\text { Eyeball rupture due to ocular trauma is a major public health problem } \\
\text { with a high global incidence. In contrast, non-trauma case of spontaneous } \\
\text { eyeball rupture is extremely rare and is never been reported in Indonesia. } \\
\text { In this report, we present a patient with spontaneous right eyeball rupture } \\
\text { due to acute glaucoma secondary to hyper mature cataract. Although } \\
\text { eyeball rupture in both trauma and non-trauma cases have the same poor } \\
\text { outcome, non-trauma case of spontaneous eyeball rupture is preventable. } \\
\text { Therefore, proper management and evaluation of the patients with } \\
\text { cataract and glaucoma are necessary to avoid this rare and devastating } \\
\text { outcome. }\end{array}$} \\
\hline & \\
\hline & \\
\hline OI : 10.20885/JKKI.Vol10.Iss2 & \\
\hline & \\
\hline & \multirow[b]{2}{*}{$\begin{array}{l}\text { Ruptur bola mata karena trauma merupakan masalah kesehatan } \\
\text { masyarakat yang serius dan memiliki insidensi global yang tinggi. } \\
\text { Sebaliknya, ruptur bola mata spontan pada kasus non-trauma sangatlah } \\
\text { jarang dan belum pernah dilaporkan di Indonesia. Pada naskah ini, kami } \\
\text { mempresentasikan seorang pasien dengan ruptur bola mata kanan spontan } \\
\text { karena glaukoma akut dan katarak hipermatur. Meskipun ruptur bola } \\
\text { mata pada kasus trauma dan non-trauma sama-sama memiliki prognosis } \\
\text { yang buruk, ruptur bola mata pada kasus non-trauma dapat dicegah. Oleh } \\
\text { karena itu, tatalaksana dan evaluasi pasien dengan katarak dan glaukoma } \\
\text { sangat penting untuk mencegah luaran yang langka dan buruk ini. }\end{array}$} \\
\hline & \\
\hline
\end{tabular}

\section{INTRODUCTION}

Eyeball rupture is the most serious type of eye injury with the worst prognosis, which is mainly caused by ocular trauma. Ocular trauma has a very high global incidence. The estimated global incidence for this case was 250,000 case in 2013 (3.5/100,000 person per year). ${ }^{1}$ The number of cases was higher in Asia. In Singapore, the annual incidence of hospitalized ocular trauma was 12.6 per 100,000 population. Furthermore, in urban population of India, there were at least 1 in every 25 people, who suffered from ocular trauma. ${ }^{2}$ In contrast, non-trauma case of spontaneous eyeball rupture is extremely rare. We found only 1 similar case reported worldwide in the last decade. ${ }^{3}$ In the best of our knowledge, this is the first non-trauma case of spontaneous eyeball rupture reported in Indonesia.

\section{CASE REPORT}

A 75-year-old female was admitted to our emergency department due to right eye pain and bleeding 1 hour before the time of admission. She had a history of cataract on both of her eyes 2 years ago. Her visual acuity was gradually decreased since then. According to the patient, she was only able to see the light through her right eye since 1 month ago. Her right eye was red and painful since 1 day before the time of admission. The history of trauma on her right eye was denied by the patient. At the time of admission, she was alert with blood pressure 
150/100 mmHg, heart rate 90 beats per minute, respiratory rate 20 breaths per minute, body temperature $36.5^{\circ}$, and random blood glucose $91 \mathrm{mg} / \mathrm{dL}$. Her pain score was 6, which assessed using a visual analogue scale. The visual acuity of her right eye was 0 or no light perception, while the visual acuity of her left eye was $1 / 300$. The bleeding was mild and was initially controlled by the application of sterile gauze with light pressure on her right eye. The examination of her right eye showed the complete protrusion of the intraocular tissue (Figure 1). Meanwhile, the examination of her left eye showed a hyper mature cataract with negative shadow test on the lens, no injection or lesion on the conjunctiva, and no injection or lesion on the sclera. The intravenous metamizole was administered to reduce the pain, followed by a careful wound toilette using sterile gauze and sterile normal saline. After complete systemic and laboratory examination, our senior ophthalmologist decided to perform evisceration for the right eye of the patient. The evisceration procedure was performed in the operating room under general anaesthesia. There was no complication during and after the procedure. She was discharged from the hospital 3 days later without any problems. During the 3 days of hospitalization, further examination of the left eye was performed. The tonometry examination showed $20 \mathrm{mmHg}$ of intraocular pressure (IOP) and the gonioscopy examination showed a slightly narrowed anterior chamber angle. The operative management for the hyper mature cataract of her left eye was scheduled on 2 weeks later.

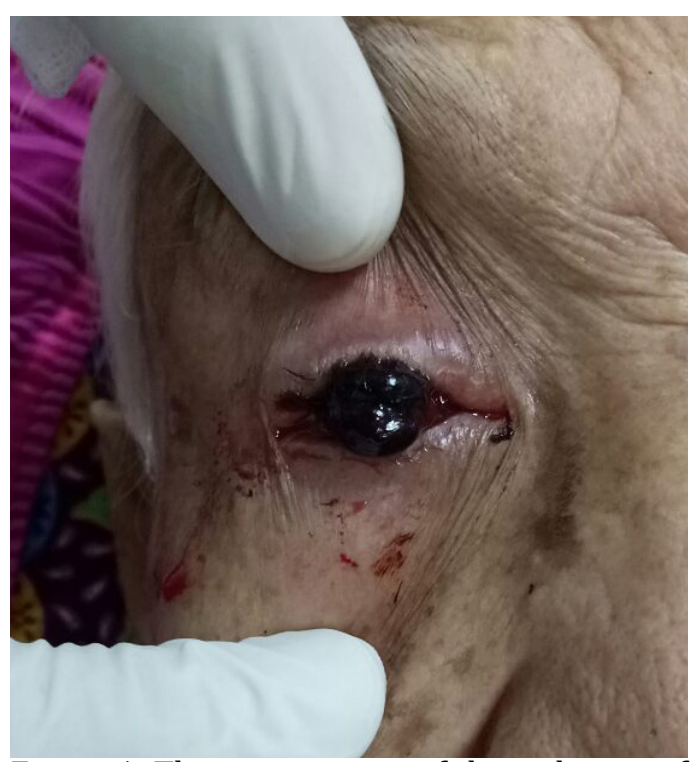

Figure 1. The examination of the right eye of the patient showed complete protrusion of the intraocular tissue.

\section{DISCUSSION}

Cataract and glaucoma are the first and the second most prevalent cause of visual loss worldwide. ${ }^{4}$ These abnormalities are often present concurrently. Glaucoma can be the risk factor of cataract and vice versa. In our case, hyper mature cataract of the patient is presumed to be the risk factor of the development of acute glaucoma, which results in the spontaneous rupture of her right eyeball. In elderly with hyper mature cataract, acute open-angle glaucoma may occur as the result of the lenticular material leakage through an intact lens capsule. ${ }^{5}$ The high molecular proteins, which are leaking from the 
lens, obstruct the aqueous flow on the trabecular meshwork. Furthermore, the IOP will be raised and glaucoma occurs. The presentations of this condition are the red eye, painful eye, history of gradual decrease of visual acuity reflecting the progression of the cataract, edematous cornea, high IOP, open-angle anterior chamber, and heavy flare. If left untreated, the spontaneous eyeball rupture may occur as the worst and the rarest complication of glaucoma, especially in elderly patient. $^{3}$

The reduction of IOP is the main goal of the management of glaucoma. ${ }^{5,6}$ Long term reduction of the IOP was presented by patient of cataract after cataract surgery. This reduction was even more significant in the case of cataract with concurrent glaucoma. In the patient with a high preoperative IOP, cataract surgery alone can significantly reduce the IOP. ${ }^{6,7}$ However, the reduction of IOP should not be expected from cataract surgery alone, if the patient had a low preoperative IOP (15-17 $\mathrm{mmHg})$. Some of the patients with a low preoperative IOP was even reported to have a higher IOP after cataract surgery. ${ }^{7}$ The underlying pathogenesis of these findings is still poorly understood.

In our case, the IOP of the patient's left eye was $20 \mathrm{mmHg}$. Therefore, cataract surgery was expected to produce a significant reduction of the IOP and the development of glaucoma could be prevented. Since the long term reduction of the IOP was reported in the patient with high preoperative IOP, this surgery will be beneficial for our patient, who was difficult to routinely visit the hospital for close monitoring.

\section{CONCLUSION}

Spontaneous eyeball rupture in acute glaucoma secondary to hyper mature cataract is extremely rare and has a very poor outcome. Proper management and evaluation of the patients with cataract and glaucoma are necessary to avoid this rare and devastating outcome.

\section{CONFLICT OF INTEREST}

None declare.

\section{Acknowledgement}

The author would like to thank Elsa Yunita for her help in the making of this article.

\section{REFERENCES}

1. Bojikian KD, Stein AL, Slabaugh MA, Chen PP. Incidence and risk factors for traumatic intraocular pressure elevation and traumatic glaucoma after open-globe injury. Eye 2015; 29(12):1579-84.

2. Feng K, Wang CG, Hu YT, Yao Y, Jiang YR, Shen LJ, et al. Clinical features and prognosis of eyeball rupture: eye injury vitrectomy study. Clinical and Experimental Ophthalmology 2015;43(7):629-36.

3. Park D, Park JS, Kang HY, Lew H. Spontaneous eyeball rupture in a 94-year old patient. Journal of the Korean Ophthalmological Society 2011;52(6):734-7.

4. Berdahl JP. Cataract surgery to lower intraocular pressure. Middle East African Journal of Ophthalmology 2009;16(3):119-22.

5. Papaconstantinou D, Georgalas I, Kourtis N, Krassas A, Diagourtas A, Koutsandrea C, et al. Lens-induced glaucoma in the elderly. Clinical Intervention in Aging 2009;4:331-6.

6. Slabaugh MA, Chen PP. The effect of cataract extraction on intraocular pressure. Current Opinion in Ophthalmology 2014;25(2):1226.

7. Poley BJ, Lindstorm RL, Samuelson TW, Schulze R. Intraocular pressure reduction after phacoemulsification with intraocular lens implantation in glaucomatous and non-glaucomatous eyes: evaluation of a causal relationship between the natural lens and open-angle glaucoma. Journal of Cataract and Refractive Surgery 2009;35:194655. 